www.jmscr.igmpublication.org

Impact Factor (SJIF): 6.379

Index Copernicus Value: 71.58

ISSN (e)-2347-176x ISSN (p) 2455-0450

crossref DOI: _https://dx.doi.org/10.18535/jmscr/v6i3.138

Journal Of Medical Science And Clinical Research

\title{
Occurrence and Multiple Antibiotic Susceptibility Profile of Bacterial Pathogens Isolated from Patients with Chronic Respiratory Diseases
}

Authors

Thonda Oluwakemi Abike ${ }^{1}$, Oluduro Anthonia Olufunke ${ }^{2}$, Osuntokun, Oludare Temitope $^{3}$, Aladejana, Oluwatoyin Modupe ${ }^{4}$, Ajadi, Fatimah Adenike ${ }^{5}$

${ }^{1,4}$ Dept of Biological Sciences, Microbiology Unit, Kings University, Ode Omu, Osun State, Nigeria

${ }^{2,5}$ Dept of Microbiology, Faculty of Science, Obafemi Awolowo University, Ile-Ife, Osun State, Nigeria

${ }^{3}$ Dept of Microbiology, Faculty of Science, Adekunle Ajasin University, Akungba Akoko, Ondo, Nigeria

Corresponding Author

Thonda Oluwakemi, Abike

P.O Box 960, Enuwa, Ile-Ife, $+2348038419096,+2347052268339$

\begin{abstract}
Objectives: The present study reported the antibiotic susceptibility profile and pattern of pathogens isolated from in- and out-patients with respiratory tracts infections.

Methods: Sputum and throat swab samples were collected aseptically from subjects and cultured on the appropriate bacteriological media. Bacterial isolates were identified using biochemical tests and the identity of the isolate was later confirmed using Analytical Profile Index 20E kit. Antimicrobial susceptibility was performed by standard methods.

Results: Out of all specimens, 97.2\% yielded a positive growth and species of various bacteria were isolated. The highest prevalence of bacteria isolated was observed in Klebsiella species (25.6\%), Enterobacter species (18.8\%) and the least was Shigella sp (2.5\%). The susceptibility and resistance patterns of one bacterial isolates varied to the other depending on the antibiotics. The bacteria sp was resistant to other antibiotics. Many of the bacteria shows 96.1\%, 95.1\%, 88.3\% sensitivity to Ofloxacin, Ciprofloxacin and Imipenem respectively. All the pathogens was $100 \%$ resistant to Piperacillin, $<68.6 \%$ resistant to third generation cephalosporin.

Conclusions: The study concluded that the diseases in the study location is becoming rampant. The susceptibility of the pathogens to imipenem, ofloxacin and nitrofurantoin showed the effectiveness of these antibiotics in the treatment of infections caused by these organisms.

Keywords: Antibiotic sensitivity, Bacterial Pathogens, Chronic, Respiratory diseases.
\end{abstract}

\section{Introduction}

Chronic respiratory diseases are among the leading causes of death throughout the world (Lozano et al., 2012). Respiratory diseases is the diseases of the respiratory system. These diseases include amongst others diseases of the lung, bronchitis, bronchial tubes, trachea and pleural cavity, lower and upper respiratory tract. They can range from mild or acute, which can be the common cold, to chronic or life-threatening such as bacterial pneumonia and bronchitis. Respiratory disease include asthma, chronic 
obstructive pulmonary disease (COPD) and respiratory allergies.

Respiratory diseases has a high impact on the health of populations at all ages of life and every level of morbidity. Chronic diseases like asthma, respiratory allergies and chronic obstructive pulmonary disease are the cause of almost $5 \%$ of all admissions and bed-stay, while lower respiratory diseases are responsible for $11 \%$ of deaths.

The developing countries are experiencing an increase in the prevalence of respiratory infections/ diseases in a review (Boutayeb and Boutayeb, 2005) and a projected trends of severity and frequency are likely to pose a public health challenge in those countries (Ait-Khaled et al., 2001). A higher burden of respiratory infections among the elderly or the aged could be of a concern to Africa's rapidly increasing population currently the second largest in sub-Saharan Africa (Joubert, 2006). Some risk factors have been associated with chronic respiratory diseases such include gender (Han et al, 2007), socio-economic status (WHO, 2013), tobacco smoking habits (Forey et al., 2011), occupational environment (Omland et al., 2014) and polluting fuel which are used for residential cooking/heating (TorresDuque et al., 2008).

According to World Health Organization (WHO), hundreds of millions of people suffer worldwide from a chronic respiratory diseases. Two hundred and thirty-five million people have asthma and 64 million people have COPD while millions of others suffer from other often-undiagnosed chronic respiratory diseases. The aim of this study was to determine the frequency of bacteria isolated from LRTI patient and to determine the antibiotic susceptibility pattern of the causative organisms.

\section{Methods}

Study population: A total of three hundred and thirty-five clinical samples were collected from patients attending the various Obafemi Awolowo University Teaching Hospitals and clinical wards in Ile-Ife, Nigeria. All patients had clinical evidence of respiratory infections, as determined by the clinicians.

Sample collection: The specimens were collected aseptically from patients (sputum and throat swab samples). All patients were instructed on how to collect the sputum samples aseptically and taken to the laboratory immediately for analysis. The sputum samples were collected into well-labelled sterile, wide mouthed glass bottles with screw cap tops. Using a sterile cotton swab, the inner surface of the infected throat was swabbed gently and then were transported to the laboratory.

\section{Sample Analysis}

Each sample was inoculated on MacConkey agar, Eosin methylene blue agar, Cetrimide agar and Salmonella-Shigella agar. The inoculum on the plate was streaked out for discrete colonies with a sterile wire loop. The culture plates were incubated at $37^{\circ} \mathrm{C}$ for 24 hours and observed for growth through the formation of colonies. All the bacteria were isolated and identified using morphological, microscopy and biochemical tests following standard procedures described by Sharma (2005).

\section{Identification using Analytical Profile index (API20E kit)}

The identity of the isolate was confirmed using Analytical Profile Index 20E kit (BioMérieux, Inc., France) following the manufacturer's instruction. Biochemical tests other than oxidase test were done by using API 20E test kit (BioMérieux, Inc., France). The isolates were grown on a non-selective medium (Nutrient agar) at $37^{\circ} \mathrm{C}$ for $24 \mathrm{~h}$. With a sterile wire loop, a well discrete colony was picked into $5 \mathrm{ml}$ sterile normal saline and mixed thoroughly to make a suspension. Then, $5 \mathrm{ml}$ of sterile distilled water was poured in the corrugation incubation tray to provide humid atmosphere for the incubation of the test bacteria. The plastic strips holding twenty mini-test tubes were filled with bacterial suspension using a sterile Pasteur pipette 
according to manufacturer's directions. The plastic lid was placed on the tray, and the strips were incubated in a humidity chamber at $37^{\circ} \mathrm{C}$ for 18 $24 \mathrm{~h}$. The colour reactions were read (some with the aid of added reagents as supplied by the kit) after the incubation for bacterial identifications. The data were analysed by the manufacturer's software and positive results with $\geq 89 \%$ probabilities were confirmed for the different organisms

\section{Antibiotic susceptibility testing: The} antimicrobial sensitivity of the test strains of thirteen antibacterial drugs was done using the Kirby-Bauer disk diffusion method (Bauer et al., 1966). The antibiotic discs (Oxoid Ltd, Basingstoke, Hampshire, England) of varying and specific concentrations were used for the tests and they include; cefotaxime (30ug), piperacillin (10ug), augmentin (2ug), cefoxitin (30ug), ceftazidime $(30 \mu \mathrm{g})$, cefuroxime $(30 \mu \mathrm{g})$, ofloxacin (5 $\mu \mathrm{g}$ ), cefixime (5ug), imipenem (10ug), gentamicin (10ug), ciprofloxacin (5ug), ofloxacin (5ug) and nitrofurantoin (300ug). These discs were firmly placed on the surface of the culture plates using a sterile forceps and incubated in an inverted position at $37{ }^{\circ} \mathrm{C}$ for $18 \mathrm{~h}$. Resistance profiles of the isolates were determined by measuring the diameter of zones of inhibition of each antibiotic on the bacterial isolates between 16-18 $\mathrm{h}$ of incubation and comparing these zones of inhibition with CLSI (2013).

\section{Results}

A total of 335 samples were obtained from the outpatient and inpatient of which $56 \%$ were male and $44 \%$ were female (Table 1). Klebsiella species $(35 \%)$ was found to be the predominant organism which was isolated, followed by Enterobacter species (13\%), Providencia species (1\%) and Proteus species (1\%) (Figure 1).

Resistance to antibiotics varied greatly among the isolates. Enterobacter sp showed $81 \%$ resistance to augmentin, amoxillin-clavulanic acid (76\%), cefoxitin (52\%), cefixime $(44 \%)$ cefotaxime (32\%), piperacillin (100\%) and cefuroxime (38\%). However, Enterobacter sp were susceptible to gentamicin, ciprofloxacin and the other antibiotics. It was $100 \%$ susceptible to imipenem. Klebsiella sp was $69 \%$ resistant to amoxillinclavulanic acid, augmentin (54.2\%), cefixime (30\%) and ceftazidime (43\%) but Klebsiella sp were susceptible to ciprofloxacin, imipenem and ofloxacin. All other isolates were susceptible to ciprofloxacin, imipenem, nitrofurantoin and ofloxacin except $P$. aeruginosa $(72.3 \%)$ that was resistant to nitrofurantoin (Table 2). Imipenem was the most sensitive drug to all isolates.

The isolates were highly resistant to class penicillins, cephalosporins and beta-lactam inhibitor but were susceptible to monobactam and fluoroquinolones (Figure 2).

The multiple antibiotic resistance (MAR) phenotypes of bacterial isolates recovered from patients diagnosed with chronic respiratory diseases in Ile-Ife showed diversities of MAR patterns which occurred among the isolates of which $0.75 \%$ and $0.25 \%$ developed resistance to six and seven classes of antibiotics tested respectively. Resistance to five classes of antibiotics was $(5.5 \%)$, four classes of antibiotics (21.6\%) and three classes of antibiotics (65.3\%) (Table 3).

Table 1: Distribution of bacteria pathogens from patients in relation to Gender

\begin{tabular}{lccc}
\hline Gender & Number examined (\%) & $\begin{array}{c}\text { Number with positive } \\
\text { growth (\%) }\end{array}$ & $\begin{array}{c}\text { Number without positive } \\
\text { growth (\%) }\end{array}$ \\
\hline Female & $148(44.1)$ & $135(43.4)$ & $13(54.1)$ \\
Male & $187(55.8)$ & $176(56.5)$ & $11(45.8)$ \\
Total & $\mathbf{3 3 5}(\mathbf{1 0 0})$ & $\mathbf{3 1 1}(\mathbf{1 0 0 )}$ & $\mathbf{2 4}(\mathbf{1 0 0})$ \\
\hline
\end{tabular}




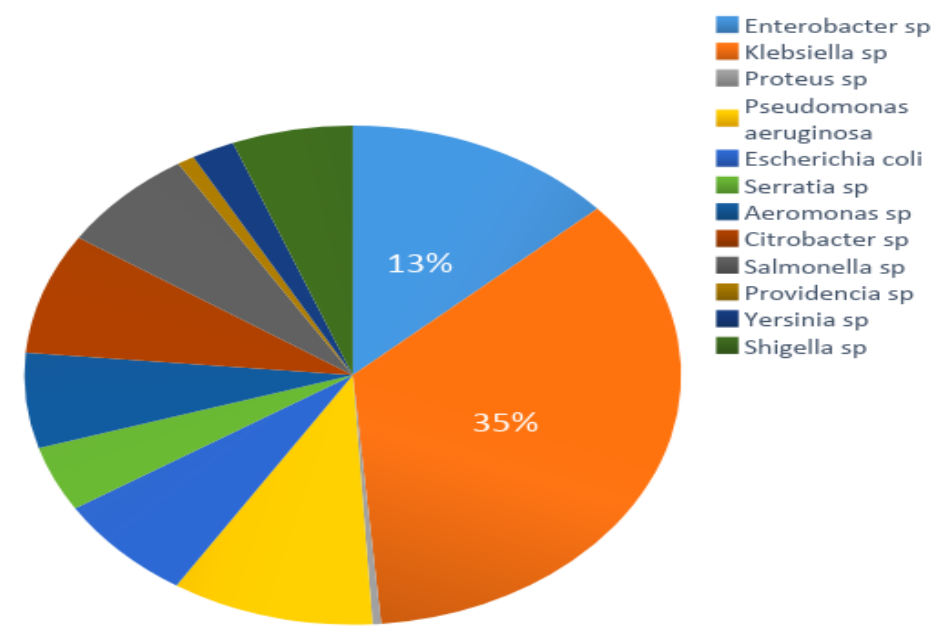

Figure 1: Percentage distribution of Bacterial Isolates Cultured from Sputum and throat swab samples

Table 2: Resistance pattern of bacterial isolates from Respiratory tract infections to antibiotics

\begin{tabular}{|c|c|c|c|c|c|c|c|c|c|c|c|c|c|}
\hline \multirow[b]{2}{*}{ Bacterial pathogens } & \multirow[b]{2}{*}{ AUG } & \multicolumn{12}{|c|}{ Percentage of isolate resistant to } \\
\hline & & AMC & CAZ & CPR & CRX & CTX & CXM & FOX & GEN & IPM & NIT & OFL & PRL \\
\hline $\begin{array}{l}\text { Enterobacter } \\
(n=63)\end{array}$ & 80.9 & 76.1 & 26.9 & 1.58 & 38.0 & 31.7 & 44.4 & 52.3 & 15.8 & 0 & 9.5 & 1.58 & 100 \\
\hline Klebsiella sp $(\mathrm{n}=166)$ & 54.2 & 68.6 & 42.7 & 4.2 & 30.1 & 32.5 & 44.5 & 14.4 & 12.6 & 4.2 & 6.0 & 4.2 & 100 \\
\hline Proteus sp $(\mathrm{n}=2)$ & 0 & 50.0 & 100 & 0 & 0 & 0 & 0 & 0 & 0 & 0 & 0 & 0 & 100 \\
\hline$P$. aeruginosa $(n=47)$ & 80.8 & 91.4 & 14.8 & 6.3 & 74.4 & 38.2 & 80.8 & 57.4 & 10.6 & 19.1 & 72.3 & 0 & 100 \\
\hline $\begin{array}{l}\text { Escherichia coli } \\
(\mathbf{n}=33)\end{array}$ & 51.5 & 87.8 & 48.4 & 12.1 & 36.3 & 27.2 & 39.3 & 6.0 & 21.2 & 0 & 6.0 & 9.0 & 100 \\
\hline Serratia $\mathbf{s p}(\mathrm{n}=\mathbf{2 0})$ & 70.0 & 90.0 & 25.0 & 10.0 & 55.0 & 20.0 & 30.0 & 35.0 & 10.0 & 10.0 & 20.0 & 10.0 & 100 \\
\hline Aeromonas sp $(n=29)$ & 55.2 & 72.4 & 38.0 & 3.4 & 65.5 & 44.8 & 62.0 & 27.5 & 13.8 & 0 & 17.2 & 3.4 & 100 \\
\hline Citrobacter sp $(n=37)$ & 48.6 & 64.8 & 18.9 & 0 & 24.3 & 24.3 & 32.4 & 16.2 & 2.7 & 0 & 8.1 & 0 & 100 \\
\hline Salmonella sp $(n=32)$ & 65.6 & 90.6 & 46.8 & 0 & 46.8 & 40.6 & 56.2 & 0 & 9.4 & 6.25 & 9.4 & 0 & 100 \\
\hline Providencia sp $(n=4)$ & 100 & 75.0 & 100 & 0 & 100 & 100 & 100 & 0 & 25.0 & 0 & 0 & 25.0 & 100 \\
\hline Yersinia $\mathbf{s p}(\mathbf{n}=10)$ & 90.0 & 80.0 & 60.0 & 0 & 80.0 & 80.0 & 80.0 & 20.0 & 10.0 & 0 & 10.0 & 0 & 100 \\
\hline Shigella $\mathrm{sp}(\mathrm{n}=28)$ & 53.5 & 78.5 & 60.7 & 7.14 & 60.7 & 57.1 & 71.4 & 32.1 & 10.7 & 3.5 & 25.0 & 7.14 & 100 \\
\hline
\end{tabular}

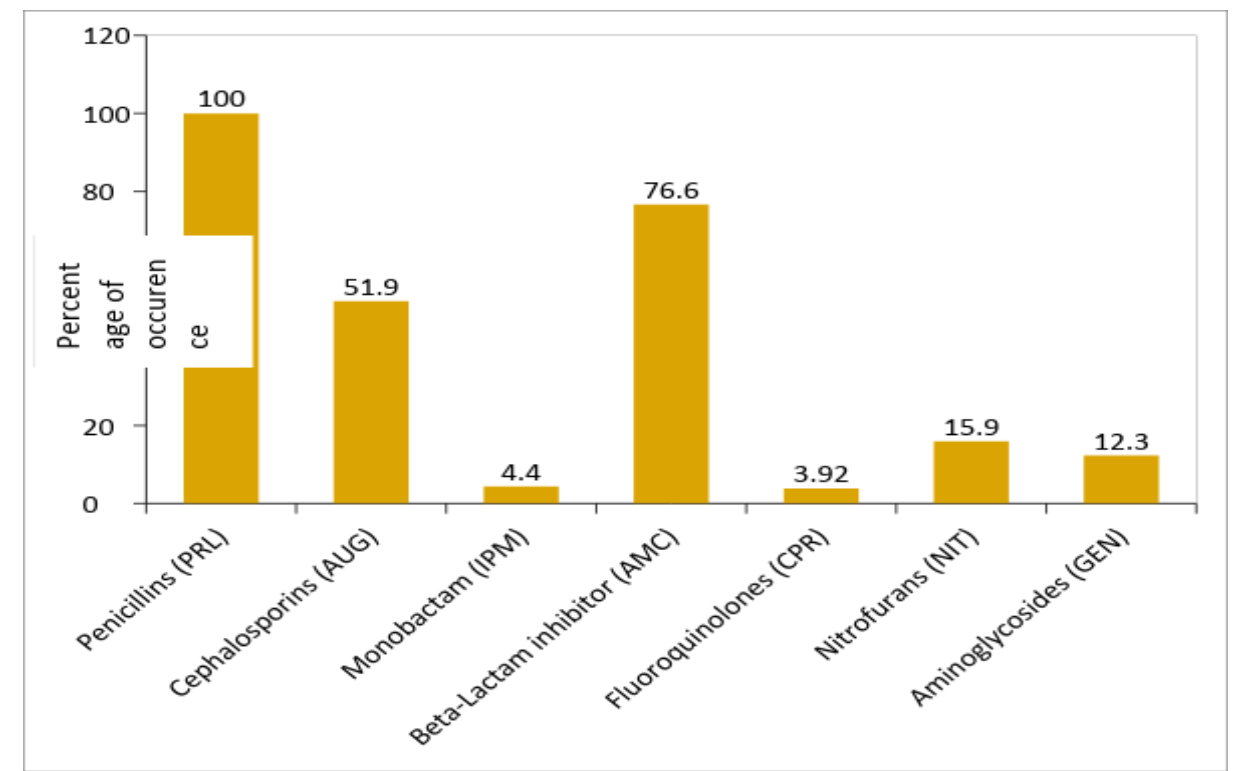

Figure 2: Occurence of resistance of bacterial isolates from clinical samples of patients with respiratory tract infections to various classes of antibiotics. 
Table 3: Multiple Antibiotic Resistance Pattern of Bacterial Isolates to Classes of antibiotics

\begin{tabular}{|c|c|c|c|}
\hline $\begin{array}{l}\text { Number of classes of } \\
\text { antibiotics tested }\end{array}$ & $\begin{array}{l}\text { Multiple antibiotics resistance profile of the } \\
\text { isolates }\end{array}$ & Frequency & Overall (\%) \\
\hline 2 & AUG, PRL & 25 & $25(6.28)$ \\
\hline 3 & $\begin{array}{l}\text { AMC, CAZ, PRL } \\
\text { AMC, GEN, PRL } \\
\text { AUG, OFL, PRL } \\
\text { AUG, NIT, PRL } \\
\text { AUG, IPM, PRL } \\
\text { AUG, GEN, PRL }\end{array}$ & $\begin{array}{c}233 \\
9 \\
2 \\
8 \\
4 \\
4\end{array}$ & $260(65.3)$ \\
\hline 4 & $\begin{array}{l}\text { AMC, CAZ, GEN, PRL } \\
\text { AMC, CAZ, IPM, PRL } \\
\text { AMC, CAZ, OFL, PRL } \\
\text { AMC, GEN, NIT, PRL } \\
\text { AUG, IPM, NIT, PRL } \\
\text { AUG, GEN, OFL, PRL } \\
\text { AMC, CAZ, NIT, PRL }\end{array}$ & $\begin{array}{c}22 \\
3 \\
3 \\
1 \\
3 \\
6 \\
48\end{array}$ & 86 (21.6) \\
\hline 5 & $\begin{array}{l}\text { AUG, GEN, NIT, OFL, PRL } \\
\text { AMC, CAZ, IPM, NIT, PRL } \\
\text { AMC, CAZ, GEN, NIT, PRL } \\
\text { AMC, CAZ, GEN, OFL, PRL } \\
\text { AMC, CAZ, OFL, NIT, PRL }\end{array}$ & $\begin{array}{c}1 \\
12 \\
3 \\
5 \\
1\end{array}$ & $22(5.5)$ \\
\hline 6 & $\begin{array}{l}\text { AMC, CAZ, GEN, NIT, OFL, PRL } \\
\text { AMC, CAZ, IPM, OFL, NIT, PRL } \\
\text { AMC, CAZ, OFL, GEN, IPM, PRL }\end{array}$ & $\begin{array}{l}1 \\
1 \\
1\end{array}$ & $3(0.75)$ \\
\hline 7 & AMC, CAZ, GEN. IPM. NIT, OFL, PRL & 1 & $1(0.25)$ \\
\hline
\end{tabular}

\section{Discussion}

A high prevalence of chronic respiratory infection was recovered in males than females. The reason for this high prevalence/risk of respiratory infections in males maybe attributed to smoking and use of tobacco, alcohol consumption, etc., thereby causing decreased local immunity in the respiratory tract of such due to defective mucociliary clearance, mucous plugging, airway collapse, respiratory muscle fatigue and the effect of medications used. Patients in the older age group are very more susceptible to Gram-negative pneumonia infection because of waning immunity and pulmonary defense mechanisms, underlying chronic diseases (malnutrition, diabetes mellitus, emphysema, uraemia etc.) silent aspiration and increased exposure to antibiotics (Sunil and Gaurav, 2016).

The bacteria isolates from the samples included $K$ pneumoniae, Enterobacter cloacae, $P$. aeruginosa and E. coli. These isolates clinical pathogens isolated which were similar to the results obtained by Kumari in India (Kumari et al.,2007) and it also falls within the range of frequencies reported in other countries such as Nigeria (El-Mohamed et al., 2010; Okesola and Oni, 2009) and Turkey (Ezgi Ozilmaz et al., 2005).

Klebsiella spp was the most prevalence bacterial isolates among all, Shailaja et al. (2004) had also reported $K$. pneumoniae $(32.26 \%)$ as the most prevalent bacterial isolates. Mustaq Ahmed et al. (2013), Egbe et al. (2011) and Akingbade et al. (2012) have also reported Klebsiella sp to be the most predominant isolates recovered from patients with LRTIs. Due to variation in age, season, the type of population at risk, and various other factors, the differences in the prevalence of bacterial isolates in different studies were also observed in India (Collee and Watt, 2006). 
The sensitivity tests indicated that the isolates were resistant to one or more antibiotics, although generally, a low percentage of the isolates were sensitive to some of the antibiotic tested. This observation poses a serious public health problem and also documented in other studies also (Gauchan et al., 2006; Goel et al., 2009). The pattern of antibiotic resistance recorded in this study among isolates is correlated with the results obtained from Gauchan et al. (2006) and Kumari et al. (2007). Although P. aeruginosa has been shown to be resistant to many antimicrobioal agents as was found in our study as various mechanism of resistance can be involved including ESBL and ampC beta lactamase production, in its resistance.

There is an alarmingly high multi-drug resistance rate which was observed to cephalosporins, beta lactam, beta-lactamase inhibitors, against Gram negative microorganisms because of various mechanism of resistance transferred to one bacteria from other bacteria.

The increase in the antibiotic non-susceptible strains of pathogens in recent years could be attributed to their indiscriminate and promiscuous use. This alarming situation developed due to widespread confusion over the aetiology of respiratory infection caused primarily by virus or bacteria which led to the emergence of resistant microorganism. Use of combined therapy and its use for long duration increase the opportunity of resistant strains for acquisition and/or amplification of their resistant mechanisms. In previous era, first line medications were effective and cheaper. With the onset of newer resistance mechanism, newer treatments are developing which are effective but proving too costly to the vast majority of cases living in poor developing countries.

\section{Conclusion}

The level of antibiotic resistance, is a serious public health problem that need serious attention for timely and proper diagnosis of the major microbial causes of the respiratory infections, based on antibiotic susceptibility testing in order to administer appropriate therapy of the causative agent. This study revealed that carbapenems and fluoroquinolones are the best choice of drugs for the effectiveness in the treatment of infections caused by these organisms.

Judicious use of antibiotics must be done by the clinicians, pharmacist and others who are incorporated in drug delivery system so that we can make a check on the emergence of pathogens acquiring drug resistance to various antibiotics having a role in critical condition or emergency. Also, there is a need to start empirical therapy and change of antibiotic must be made when we receive the antibiotic susceptibility pattern for that microorganism to hamper the development of resistance mechanism.

\section{Conflict of Interest: None}

Funding Source: Self-funding

Ethical Approval: The ethical clearance with protocol number (ERC/2015/09/04) approval was duly obtained from the Ethics and Research Committee of the Hospitals Managements and the subjects gave informed consent to the work.

\section{References}

1. Ait-Khaled N, Enarson D, Bousquet J. Chronic respiratory diseases in developing countries: the burden and strategies for prevention and management. Bull World Health Organ. 2001; 79(10):971-9.

2. Akingbade OA, Ogiogwa JI, Okerentugba PO, Innocent-Adiele $\mathrm{HC}$ et al. Prevalence and antibiotic susceptibility pattern of bacterial agents involved in lower respiratory tract infections in Abeokuta, Ogun State, Nigeria. Report and Opinion 2012:4(5):25-30.

3. Boutayeb A, Boutayeb S. The burden of non-communicable diseases in developing countries. Int J Equity Health. 2005, 4(2) $: 1-8$.

4. CLSI-Clinical Laboratory Standards Institute. (2013). Performance Standards 
for Antimicrobial Susceptibility Testing; Twentieth Informational Supplement, CLSI document 2013, vol. 30. Villanova, PV: CLSI; 2013, M100-S20.

5. Collee JG, Watt B. Bacterial infection of respiratory tract. Topley and [15] Wilson's Principles of Bacteriology, Virology, and Immunity Vol. III. 10 ${ }^{\text {th }}$ edition. 2006 BC Decker, Inc. UK.

6. Egbe CA, Ndiokwere C, Omoregie R. Microbiology of Lower Respiratory Tract Infections in Benin City, Nigeria. Malaysian J Med Sci 2011;18(2):27-31.

7. El-Mahmood AM, Isa, A, Tirmidhi SB. Antimicrobial susceptibility of some respiratory tract pathogens to commonly used antibiotics at the Specialist Hospital, Yola, Adamawa State, Nigeria. J. Clin. Med. Res. 2010 2(8), pp. 135-142.

8. Ezgi OO, Arikan A, Meral G, Kamruddin A. Major bacteria of community acquired respiratory tract infection in Turkey. Jpn. J. Infect. Dis., 2005. 58:50-52.

9. Forey BA, Thornton AJ, Lee PN. Systematic review with meta-analysis of the epidemiological evidence relating smoking to COPD, chronic bronchitis and emphysema. BMC Pulm Med. 2011, 11(36):1-61.

10. Gauchan P, Lekhak B, Sherchand JB. The Prevalence of lower respiratory tract infection in adults visiting Tribhuvan University Teaching Hospital. J Inst Med. 2006;28(2):10-14.

11. Goel N, Chaudhary U, Aggrawal R, Bala $\mathrm{K}$. Antibiotic sensitivity pattern of gram [16] negative bacilli isolated from lower respiratory tract of ventilated patients of intensive care unit. Indian $J$ Crit Care Med. 2009;13(3):148-51.

12. Han MK, Postma D, Mannino DM, Giardino ND, Buist S, Curtis JL, et al. Gender and chronic obstructive pulmonary disease: why it matters. Am J Respir Crit Care Med. 2007; 176(12): 1179-84.
13. Joubert J, Bradshawb D. Chronic disease lifestyle in South Africa: 19952005. South African Medical Research Council 2006; 1:204-219, Techical report

14. Kumari HBV, Nagarathna S, Chandramuki A. Antimicrobial resistance pattern among aerobic gram-negative bacilli of lower respiratory tract illness in the community. Thorax. 2007;56:109-14.

15. Lozano R, Naghavi M, Foreman K, Lim S, Aboyans V, Abraham J, et al. Global and regional mortality from 235 causes of death for 20 age groups in 1990 and 2010: a systematic analysis for the Global Burden of Disease Study 2010. Lancet. 2012; 380(9859):2095-128.

16. Mustaq AS, Jakribettu RP, Meletath SK, Arya B, Shakir VPA. Lower Respiratory Tract Infections (LRTIs): an insight into the prevalence and the antibiogram of the gram negative respiratory, bacterial agents. J Clin Diag Res 2013:1-4.

17. Okesola AO, Oni AA. Antimicrobial resistance Among Common Bacterial Pathogens in South Western Nigeria. AmEurosian, J. Environ. Sci. 2009 5(3): 327330.

18. Omland O, Würtz ET, Aasen TB, Blanc P, Brisman JB, Miller MR, et al. Occupational chronic obstructive pulmonary disease: a systematic literature review. Scand J Work Environ Health. 2014;40(1):19-35.

19. Shailaja VV, Pai LA, Mathur DR, Lakshmi V. Prevalence of Bacterial and Fungal Agents Causing Lower Respiratory Tract Infections in Patients with Human Immunodeficiency Virus Infection. Indian J Med Microbiol. 2004;22(1):28-33.

20. Sharma, R., Sharma, C. L. and Kapoor, B. (2005). Antibacterial resistance: current problems and possible solutions. Indian Journal of Medical Sciences 59, 120-129.

21. Sunil V, Gaurav D (2016) Prevalence of LRTI in Patients Presenting with 
Productive Cough and Their Antibiotic Resistance Pattern. Journal of Clinical and Diagnostic Research. 10(1): 09-12

22. Torres-Duque C, Maldonado D, PérezPadilla R, Ezzati M, Viegi G. Biomass fuels and respiratory diseases: a review of the evidence. Proc Am Thorac Soc. 2008;5(5):577-90.

23. World Health Oragnisation. Review of Evidence on Health Aspects of Air Pollution - REVIHAAP Project. 2013. Techinical report. 